\title{
DIVANUL DE GHEAŢĂ SOSIREA, MARŢEA ÎNTR-UN FULGER NEGRU
}

\author{
Veronica Balaj \\ Jurnalista Radio -TV,
}

Scriitoare, Membra a Uniunii Scriitorilor din Romania, USR;

Membra a Academiei Romano-Americane de arte si Stiinte, ARA;

Membra a Academiei "Citta di Roma"

Membra a Asociatiei Scriitorilor de limba romana din Canada

Noaptea se agăţa de gulerele caftanelor înblănite şi de ciucurii poalelor şi de mânecile înzorzonate cu dantelării şi brocarturi acum scumpe şi la vedere căci se pornise un vânt arţăgos, ascuţit care muta din loc şi siluetele zdrahoane ale celor 12 ciohodari însoțitori ai temutului Aga Mustafa Hambar Erini, porniţi cu înaltă şi grea poruncă de la însuşi Sultanul spre domnul Ţării Româneşti, Constantin Brancoveanu. Vrăjmăşia vântului în acea zi de 23 martie, din calendarul anului 1714 părea un semn potrivnic misiunii încredinţate dar, neluat în seamă de firea lor ostăşească, (doar ei erau aleşii pentru a o înfăptui), se simţeau mândri şi hotărâţi a pune în acţiune toată forţa lor pentru ca ordinul înaltei dregătorii să fie împlinit întocmai.

- Mai puneţi-vă o blană, prea cinstite Mustafa, vântul din ţara asta bate a nesupunere. Chiar şi vântul, nu mai spun de ghiauri. Te atacă aşa pe la spate, mişeleş̧e, nici nu bănuieşti cum te înfăşoară, spuse cel dintâi în rangul slujitorilor aprigului Aga Mustafa.

- Ba nu! Mai degrabă aş zice că vântoasa e adusă de noi! Ha, ha ha, o purtăm la cingătoare şi o slobozim când vrem, să ştie de la bun început, "Prinţul aurului", cum e numit Brâncoveanul, care-i rostul de-am bătut atâta cale până la el, spuse râzând în hohote de satisfacţie, Aga Mustafa lăsând să se înţeleagă cum că, ar fi peste măsură de primejdios ca vreunul dintre supuşii din jurul său, slabi de fire să fie a se lăsa cât de cât impresionați de cele ce vor urma. Ar fi fost o dovadă neândoielnică de trădătoare simțire faţă de măria sa, Sultanul.

- Dreptate aveţi, înalte Aga, puterea ta şi a preacinstitei Tale minţi o să aducă spulber printre ghiaurii nesupuşi. Să fie o pildă pentru alţii din plebea Imperiului, să nu uite nicidecum măreţia Con- stantinopolului şi a înaltului nostru, slăvit Sultan, răspunse cu supuşenie ciohodarul şef punându-i demnitarului încă o blană în jurul gâtului.

Noaptea se agăţa mohorâtă şi rece, ca nişte aşchii de săbii înfipte în ochii convoiului. Până şi caii se simţeau atinşi de vremea care-i strângea de grumaji precum o viperă zburătoare de la unul la altul.

Fiecare îşi dorea să ajungă cât mai repede la Curtea Domnească.

- Plecăciune vouă, Aga, ce dar de prietenie pentru Brâncoveanu duceți în taină, nici nu se poate bănui. Îl ştiaţi cu bravă purtare faţă de prealuminata voastră persoană? Uite că nu era cinstit. Căderea în hiclenie nu se poate ierta de prea slăvitul nostru Sul$\tan$.

- Să plătească, Ghiaurul!Toată averea lui, în aur și acareturi, până şi covoarele o să fie duse la Stambul. Nu mai zic de moșii, case, palate, adunate în 25 de ani de domnie cum vor intra sub stăpânirea noastră. Toot, tot vom lua, spuse răspicat Aga Mustafa.

- Credea că nu vor ajunge la urechile Stăpânului nostru și ale lumii câte plănuise Ghiaurul cu gând ticălos!.

Se dăduse în protecția lui Carol, cel al VI-lea numit, adăugă şoptit ciohodarul care turna mai marilor săi orce informație și chiar avea răspunderea să facă acest lucru. Un secret nu adăsta niciodată, nici vorbă a fi pecetluit căci veștile umbalu ca năpârcile pe coridoarele și drumurile și încăperile imperiale otomane.

- Sabia să-i cadă cu dreptate și ascuțire asupră-i! Cantacuzinul Mihai, neamul său, pohtind la ranguri şi domnie, 1-a dat de gol, cum că se dedase şi cu rușii, lucru dovedit cu fuga unor generali într-acolo, adăugă Aga Mustafa, îndesându-și pe cap turbanul 
tivit cu blană și pietre prețioase gata, gata să-i fie săltat de vântul care o luase razna și bătea din toate părțile iar convoiul, fără de voire, se lăsa șfichiuit neavând cum să se ferească.

O adevărată furtună se rostogolea în valuri peste caftanele şi ochii turcilor primiţi cu ostentaţie chiar de la primele cotituri făcute pe tărâmul țării domnitorului român. Era un soi de oprelişte pusă de-a latul în direcţia în care galopau. Din astă pricină oboseala creștea şi odată cu ea, încolțea dorința lor de atac. Ar fi scos iataganele dacă vântul ar fi fost un dușman pe care să-1 sfârtece în bucăți. Înaintau cu osârdie și turbare ca și cum întreagă boierimea de la Curtea Domnească s-ar fi coalizat împotriva lor, uitând de vasalitate faţă de Înalta Poartă.

- Aș fi ordonat popas la un han de n-am purta firmanul ca mâine dis-de-dimineaţă să înplinim tot ce stă înscris sub sfânta pecete otomană, zise ca pentru sine, demnitarul turc. Am fi avut după pohtă și nişte fete, ar fi sosit și carafele cu vin şi muzica. Eh, da' nu-i vreme să adăstăm, o lăsăm pe altă dată..

- Precum spuneţi, mărite Aga. S-ar cuveni toate astea dar dacă înpricinatul reușește să fugă în bănuita lui capitală secretă? Cică şi-ar fi mărit apărarea la Târgovişte, îşi dădu cu părerea un ciohodar apropiat de Aga în orce fel de misiune care cerea discreţie. Deşi făceau efort să mărşăluiască cu grăbire, părea că stau mai mult pe loc. Nu se dădură bătuţi, doar erau oştenii de încredere ai măritului Sultan şi, în cele din urmă, înainte de miez de noapte, ajunseră la Curtea Domnească

Ușierii, santinelele și soldații care apărau intrarea își ascunseră cu grijă mirarea vâzându-l pe înaltul slujbaș venind pe neștiutelea dinainte. Astfel de întâmplare putea să fie a bine sau, la fel de uşor putea fi aducătoare de rele urmări. Precauţi, își făcură datoria salutându-1 după cum cerea obiceiul :

- Bine aţi venit, înălţimea voastră, Aga Mustafa!. Suntem bucuroși a vă avea în ospeție.

$\mathrm{Cu}$ plecăciuni, slujbașii de la Curtea Domnească se oferiră să-l însoțească iar alții se grăbiră să-1 anunțe pe Domnitor. Aga Mustafa Hambar Erini, acum trimisul special cu împlinirea unei misiuni grele mai fusese aici cu diverse prilejuri, unele sărbătorești ba chiar găzduirea sa era considerată altă dată un astfel de moment. Brâncovenu Domnul și-l făcuse prieten și-l omenise după rangul pe care acesta îl purta între supușii Porții.

De data asta însă, Aga Mustafa nu avea de gând să servească nimic și mai cu seamă, nu în compania Brâncoveanului pentru care se afla secret înscris ordin de mare importanță.

Duse erau vremurile cu ospețe bogate împlinite la început după un ceremonial solemn cu rostirea de către Patriah a unei închinăciuni pentru Dumnezeu, pentru sultan, domnitor și boieri. Urmau apoi, a fi servite cele mai felurite bucate iar la masa de Paște, chiar Domnitorul trimitea farfurii cu mâncare către supuşii la care ținea mai mult după care, nu lipseau clipele de înveselire cu măscărici, pehlivani, comedianți. Pe unde trecea domnitorul era întâmpinat de paiațe care zdrângăneau cu osârdie clopoței de argint.

Mulți alți slujbași sau înalți trimişi ai Porții de la Stambul fuseseră primiți după aceleași reguli. În timpul vremii călduroase, desfătarea pentru oaspeții de seamă, după ce mâncau, era să se lase în voia tihnei şi bunei dispoziţi în locurile de priveală, un fel de chioșcuri feritoare de soarele arzător în zilele de vară. Domnitorul Constantin Brâncoveanu fiind primul care construise acestea în Țara Românească.

În această noapte însă, părea că toate acestea fumegau, erau trecute printr-o pâclă lăsată peste întreaga Curte Domnească nemailăsând nici măcar un ecou.

Îndată, mai marele gărzilor de la Palat își făcu apatiția, salutând și întâmpinând oaspetele cu înflorate urări precum se obișnuia:

- Bun sosit, mărite și onorate Aga, plecăciune vouă! Ai străbătut drum lung, până aici să ne faceți onoarea şi bucuria de-a ne fi oaspete. De aveam știință de venirea ta, ai fi fost întâmpinat cu masa întinsă precum merită înalta și prețuita persoană ce ești. Poftește și aşază-te și îngăduie doar o scurtă aşteptare! Îndată becerul, ca prim bucătar ce se află, va supraveghea aducerea felurilor de mâncare ce le dorești. Deîndată i se va da de veste și Măriei Sale, de sosirea ta, prea cinstite, Aga Mustafa! Drept răspuns însă, acesta îl străpunse cu o privire cât ascuţişul unor săbii înroşite în foc, rostind aspru: 
- Nu-i vreme de taclale! Suntem obosiți, şi eu şi suita mea. Dacă vrea să afle, să știe că suntem în drum spre Hotin, de aceea am trecut și pe aici.

Ofițerul luă seamă îndată și se gândi cum ar fi mai potrivit a se arăta în purtare, nu care cumva să-1 întărâte pe cel pe care-1 știa de apropiat al Măriei Sale Brâncoveanu, iar acum, își lăsa la vedere venele umflate ale gâtului zvâcnindu-i ca și când 1-ar fi gâtuit furia. De bună seamă nu putea trece nici peste legile ospeției aşa că, rosti cu grija să nu-i fie învinovăţire mirarea sau încordarea din glas:

- Precum va fi voia voastră!, rosti cercetându-1 bănuitor pe cel sosit neanuţat în miez de noapte.

- Spune-i stăpânului tău că mâine dis-dedimineață vreau o întrevedere în Sala Divanului! Să fie chemată boierimea toată și înalții slujbași, supuși ai prea slăvitului nostru Sultan! Așa să-i spui!

Omul în uniforma armatei brâncovenești gândi în sinea lui că otomanul se arăta distant, ba chiar arogant, nu ca un prieten care intrase de multe alte ori în acest loc, doar ca să-l oblige pe Domnitor să-i intre în voie, oferindu-i câteva pungi de aur așa cum se mai întâmplase și altă dată.

Pe vremea aceea însă părea prietenos.

Acum era total schimbat. Nici urmă de vorbele meșteşugite și ligușitoare atât de obişnuite în tagma celor veniţi dinspre orient. Ceva îl îndemna pe înaltul trimis de la Poartă să scoată la vedere un arțăgos fel de-a vorbi și de-a priviri. Ofițerul, înfiorat, grijuliu să nu cadă în ghearele vreunei greșeli continuă să fie mieros în rostire, aşa cum cereau și legile ospeției:

- Precum știți, dintotdeauna, odăile sunt gata pregătite. Pentru oaspeți ca voi, ușile acestea se află deschise oricând.

- Așa să fie, răspunse bățos Mustafa și, cu-n bănuit subînțeles, făcu rotire către ieșire urmat îndată de slujitorii care-și cunoșteau obligațiile, conducându-l.

Domnului i-a fost adusă deîndată știre despre sosirea lui Aga Mustafa, despre vorbele rostite în răspăr şi despre întâlnirea de a doua zi dis-de-dimineață în Sala Divanului, în prezenţa boierimii și a înalților slujbaşi.

În timpul nopții, Brâncoveanu, avu pentru prima oară în cei 26 de ani de domnie înşiruiți, o temere care-i pătrunsese în inimă deși, mintea îl îndemna să fie în tihnă căci, doar cu un an mai înainte, la 1713, îi fusese garantată de la Stambul din nou domnia pe tronul Țării Românești.

Şi totuşi, nu-i dădea pace o flacără de îndoială mai ales dacă lua în seamă zvonurile cum că, noul mare dregător de la Constantinopol, adică Marele Vizir, Gin Ali Pașa era cunoscut ca un om foarte crud care avea pe răboj multe crime înfăptuite fără părere de rău.

„Să fi uneltit vreununul dintre Cantacuzini împotriva mea atât de abitir cum s-a mai întâmplat de altfel ? Putea fi și asta, mai ales după fuga la ruși, în plin război a generalilor orbiți de hiclenie și pohtă de mărire urmându-l pe Toma Cantacuzino. Acesta, deși din neamul său, nu poate crede că nu are harul treburilor poilticești și a făcut o greșeală de neiertat și rău mult țărişoarei noastre. Prevăzător am fost, nu pot spune că nu, trimiţând la Stambul scrisoarea aceea de credință față de Poartă. Mă perpelesc din pricini închipuite, pentru că nu mai am încredere în cei din neamul meu după câte- au făptuit. "

Brâncoveanu, primul om al țării își petrecu noaptea cântărind situația, dar tot nu-și află liniștea, prin multe fiind el trecut de-a lungul anilor de domnie și cunoscând cât erau de nelipsite ițele și intrigile schimbătoare după mersul ordinelor venite de la Stambul. Spre dimineață, găsi totuși sprijin ceva mai luminat în faptul că, primise de la Înalta Poartă încuviințarea ca fiul său Radu Brâncoveanu să o poată lua în căsătorie pe Maria, fiica lui Antioh Cantemir. De-ar fi fost vreun gând rău împotrivă-i, de bună seamă, Sultanul nu i-ar fi îngăduit căsătoria.

Pentru acest important moment care urma în familia sa, Domnița Bălaşa fusese trimisă deja la Stambul să pregătească venirea mirilor în țară. ,Oare, nu mai sunt sigur nici pe mine, că nu mă bizui pe toți cei din juru-mi, e firesc la o adică, ar trebui să nu mă mai încurc în felurite îndoieli”, își spuse luând hotărârea ca a doua zi să-1 întâmpine pe Aga Mustafa în sala Divanului, cu toată bunăvoința înțeleaptă.

\section{EȘARFA HICLENIEI}

Miercuri, zi de 24 martie, 1714, se vestise în calendar și peste întreaga Curte Domnească, însoțită de o lumină sângerie. Din clipă în clipă, aceasta se preschimba în nori porniţi pătimaș în direcții în- 
volburate, se înfruntau luând forme fantasmagorice, viclene, încăierându-se tăindu-și drum orbește prin aer. Nimeni nu avea însă timp să observe schimbarea bruscă. Se putea lesne da vina pe capriciile primăverii. Lumina părea acoperită de aripile unei păsări negre, o croncănitoare auzită deocamdată în înalturi urmând, pe neașteptate să-și răsfire întunecata-i şi primejdioasa-i întunecime şi peste Curtea Domnească și peste Țara Românească.

Fusese slobozit ordin fulgeător de la Domnul Țării ca toți dregătorii, în frunte cu vistiernicul, boierii de rang înalt, spătari, polcovnici, ispravnici să se adune la Divan, în SALA DE AUDIENȚE, unde va fi veste mare adusă de la Stambul de către Aga Mustafa Hambar Erini.

În scurtă vreme spațiul mobilat cu bănci lungi capitonate cu postav roșu, într-un stil fastuos dar sobru se umplu de caftane colorate, verzi, arămii, după rang și avere, catifele moi, acopereau băncile lungi, tapetate cu postav roșu. Catifele și țesături aduse din Veneția sau Stambul, cu mare migală încrustate îmbrăcau trupuri obosite, ascundeau inimi gata de milostivă supunere boierească sau, tainice dorinți de înavuțire și urcare în rang. Unii aveau pe chip o mâhnită temere de-a nu fi păgubiți de averi sau slujbe pentru cine ştie ce neaflate încă fapte ori vorbe rostite unde și când nu ar fi trebuit. Atâta era necesar, să șoptească vreun alt boier slujbașilor de la Poartă cine știe ce ar fi putut însemna trădare, nesupunere și, destinul întregii lor familii putea fi crunt incheiat. Cei pe care nu-i apăsa vreo vinovăție se așezaseră la locurile știute dinainte cu sfioșenie greoaie, tăcută.

$\mathrm{Nu}$ se cunoștea pricina sosirii fulgerătoare a înaltului trimis de la Stambul și asta le strecura tuturor pe șira spinării șopârla fricii. Ascunsă însă cu grijă. Deși îl știau pe Mustafa drept apropiat al Domnitoruuil, teama le sălăşluia mai totdeauna în oase și nu se încumetau niciodată a-și arăta mândria de mari boieri sau demnitari. Nici vorbă de dârzenie sau făţişă încontrare cu solii otomani. Trufia sau îndârjirea manifestată în orce îmrejurare ar fi fost o neghiobie periculoasă așa că, toți își consumau temerile în secret. Din acest motiv, în lungul și latul încăperii plana o tăcere apăsătoare, înșelătoare. Ae- rul părea un coviltir arcuit peste întreaga suflare din Sala Divanului. Armele înșiruite pe pereți, aduceau aminte de victoriile din războaie dar acum, nu prea dădeau siguranță nici unuia dintre cei prezenți, nici vorbă să le fie un scut apărător, puteau fi mai degrabă o amenințare care adăuga noi fiori de gheață.

De obicei, în această încăpere se desfășurau judecăți pentru pricini însemnate. Așadar, nici acest fapt nu suna prea bine. Culoarea sângerie a unor catifele din croiala meșteșugită a unor caftane, părea o pată amenințătoare. Ar fi putut urma să fie judecat vreunul dintre ei pentru cine știe ce vină descoperită când nici nu credeau sau chiar, putea fi o vină scornită!

Sosirea Domnitoruluil Constantin Brâncoveanu, purtând aceeaşi nobilă, impunătoare atitudine de siguranță le mai atenuă starea de plutire pe o barcă în derivă. Nimeni n-ar fi bănuit și frământările sale din noaptea trecută pricinuite de aceeași sosire neanuțată a marelui Agă.

Boierimea și ceilalţi slujbași se înclinară cu vrednică supunere, unii trăgând cu ochiul, doar, doar vor ghici din privirile Domnitorului sau ale vreunui confrate ceva care să dezlege misterul întâlnirii fulger la care erau părtași.

Aga Mustafa îl văzu pe Domnitor apropiindu-se dar când acesta-i întinse mâna, trimisul Porţii, nu schiță nici un gest. Refuza să-i răspundă la salut, chiar Domnitorului?!

Toată înalta slujitorime, chemată şi adunată în grabă pricepu că lucrurile nu sunt precum s-ar fi cuvenit, că se aflau în fața unei provocări nebănuite.

Așa ceva nu se mai pomenise. Brâncoveanu, dintr-o cumpătare înaltă, princiară, îi făcu totuși semn să se așeze, după cum era obiceiul, el rămânând în picioare, tăcut, purtând pe cap cuca din care pietrele prețioase aruncau sclipiri ascuţite ca niște aşchii de săbii îndreptate către cel care-i era oaspete dar se arăta arțăgos. Caftanul Domnitorului, de un roșu aprins, părea o flacără între podelel acoperite de covoare persane și policandrul de aur ce atârna din tavan. Din privirile îngustate, ieșite din orbitele ochilor ipocriți ai lui Mustafa, se desprinse un fulger tăios, învăluind ca o sfoară gâtul domnitorului, gata, gata să-1 ștranguleze de-ar fi fost cu putință. 
Vreme de câteva secunde aceasta fu singura mișcare în încăperea peste care, părea că se așternuseră brusc sloiuri de gheață apăsătoare sufocând răsuflarea omenească, împăienjenind ochii, înghețând mâinile și inimile tuturor. Boieri de rang mare sau mai mic, laolată se simţeau ca și când ar fi căzut într-o prăpastie de gheață.

În Sala Divanului năvălise aerul de gheață din toate iernile știute, învinse ori neștiute. Figurile slujbaşilor, indiferent de rang erau și ele din gheață.

Atitudinea jignitoare, amenințătoare a trimisului Inaltei Porţi produse înfricoșare în aşa fel încât, nimeni nu mai avea aer destul, într-o peșteră de gheață de-ar fi fost, sloiuri din gheață să fi devenit cu toții, numai atunci n-ar fi putut nici măcar să-și miște pleoapele.

Secretarul șef al Curții Domnești, Anton Maria del Chiaro, multe aflase din cărțile de istorie citite dar acum nu se putea stăpâni și tremura de parcă ar fi urmat să fie dus la eșafod. Nu se știa vinovat de nimic sau, tocmai pentru că avea cunoștință despre neasemuite drame petrecute din pricina uneltirilor marilor puteri, se îngrozi la gândul că participa la o groaznică întorsătură a vremilor și atât mai apucă să se întrebe în sinea sa: „cum voi putea oare descrie acestea?” O clipă văzu steluțe verzi în faţa ochilor și apoi, un moment, totul se întunecă în faţa sa.

Își reveni când auzi glasul de viforniţă al solului temut. Aga Mustafa Hambar Erini înfioră inimile celor prezenți în sală, rostind cu ipocrizie către Domnitor:

- Nu-i vreme de șezut și regret vestea rea pe care trebuie să ți-o dau!

Își însoți cuvintele de un gest scurt, ca o lovitură de călău, înnegrind aerul din preajmă. Așeză pe umărul Domnitorului EȘARFA NEAGRĂ, şfichiuind cu o vorbă uluitoare auzul celor care ședeau în nemișcare crezând o vreme că asurziseră dar, nu, iată că totuși au putut auzi cuvântul care zbură prin aer ca un șarpe înțepat în priviri:

\section{- MAZIL!}

Toți știau ce îseamnă asta. Era coasa morții care stătea gata să cadă peste capul Domnitorului român. Faptul întrecea orce așteptare. Constantin Brâncoveanul Domnul Țării Românești era mazilit pe dată iar cei prezenți erau aşa de uluiţi, încât nici dacă un buzdugan ar fi căzut din senin peste capetele lor nu i-ar fi putut aduce la încredera în sine. Frica se mișca înlăuntrul lor asemeni unui animal turbat, producându-le o răscolire nestăpânită și nemaisimțită altă dată.

Unii își fixau ochii în pământ, alții își înfingeau unghiile în carne, nu puțini, cuprinși de panică, își aruncau privirile rătăcind alarmate de la Domnitor la Agă. Mâhnirea li se așternuse pe chip multora, nu și-o puteau ascunde, îmbătrâniseră dintr-odată. Obida unei astfel de vești nu putea fi nici ascunsă şi nicidecum dată la o parte.

Apoi, schimbându-și glasul într-unul tunător, acuzator ca şi când ar fi avut de-a face cu un duşman și răufăcător împotriva Imperiului Otoman, Aga Mustafa dădu citire acuzării:

„Pentru că te-au găsit pe tine, Constantine Brâncovene, nevrednic și hain, ca unul care i-ai adus pe muscali la Brăila, le-ai dat zaharea, ai pus biruri nouă pe țară și ai despuiat-o cu ele și nu te-ai mulțumit cu scaunul de domnie care ți-am hărăzit și după plac țiai ales totul și stăteai mai mult acolo, pentru aceste greșeli, te scoatem din domnie și-ți poruncim să vii aici la noi cu toată casa ta și seminția ta ;pentru aceea am trimis la tine, imbrihonul cel mare."

Domnitorul replică folosind un ton de crâncenă revoltă, de-ar fi fost posibil sabia ar fi scos-o. Drama momentului nu putea fi tăiată însă în bucăți deși, Sala Divanului devenise un adevărat câmp de luptă.

- Mare nerecunoștință ! Mustrare şi umilire să mă copleșească după douăzeci şi șase de ani de credință arătată Porții?!! Prefăcătorie și nesăbuință n-am arătat. Pagubă n-am adus ci, mult aur a luat drumul Stambului și chiar tu, Mustafa ai fost adesea omenit de rangul și persoana mea. Te-ai arătat prieten. $\mathrm{Cu}$ multe fețe.

O parte dintre boieri prinseră curaj și sloboziră murmur de aprobare a celor spuse de Brancoveanu.

La o asemenea îndrăzneală, Mustafa deveni și mai aprig, înaintă în pas de atac se făcu vânăt de furie și dădu îndată ordin ca Brâncoveanu să fie pus sub pază, chiar acolo sub ochii tuturor.

Le citi apoi boierilor firmanul prin care membrii familiei Brâncoveanu erau considerați de În- 
alta Poartă haini. Necredincioși ai Imperiului se dovediseră și trebuiau pedepsiți după legile otomane ale trădării. Mai adăugă cu tunete în glas

- Care dintre boieri va îndrăzni să-l sloboade pe mazilit, va plăti cu viața și averile lor vor fi luate!

Ordinele date de Aga Mustafa căzuseră ca un trăsnet, nimic nu se mai lega de ceea ce fusese mai înainte cu câteva ore.

- Visteria şi cămara tezaurului să fie închise și strașnic păzite! adăugă ca un stăpân falnic peste tot ce fusese agonisit în atâția ani de domnie ai lui Constantin Brâncoveanu.

Domnitorul fu obligat să rămână într-unul din apartamentele sale și lăsat sub pază strașnică. și tot pe atât de umilitoare. Văzându-se închis chiar sub ochii foștilor săi oşteni și ofițeri, tare şi-ar fi dorit, omenește vorbind, ca totul să nu fie decât un coșmar. Unul abătut ca o viforniță, o întunecare a luminii soarelui, un prăpăd din care terbuia să scape. $\mathrm{Nu}$ făcea însă nici un gest cântărind ce anume năpastă s-ar putea abate și asupra copiilor și a doamnei Maria dacă el ar dovedi necugetată nesupunere într-un astfel de moment.

Spera într-o posibilă îndreptare a situației, trimiţând o scrisoare la Stambul. Dar cine avea curajul și în cine să aibă încredere? Se zbătea în sinea sa căutând o ieșire mai mult pentru a-și spăla umilirea și a-și pune familia la fereală de alte primejdii și necazuri. Trecură însă ore și ore, el neaflând nici o cale, totul i se arăta potrivnic, e drept, unii boieri încercaseră să se apropie de domn dar fuseseră ameninţaţi din nou cu tăierea capetelor şi preluarea averilor de către turci. A doua zi, în Sfânta sărbătoare de Sfânta Treime, 25 martie, 1714, sosi la
Curtea Domnească din București, imbrohorul pentru a-1 așeza pe tron, pe Ștefan Cantacuzino. Pentru prima oară în acelaşi loc se aflau doi domnitori deodată. Ca și când ar fi răsărit doi sori în acelaşi moment, supușii neștiind încotro ar fi mai nimerit să se uite.

Principele Ștefan trecu în apartamentul unde se afla Brâncoveanu și-1 asigură de credință în continuare spunând cu plecăciune și oarecare colorare a obrajilor:

- Sunt FORȚAT, Măria Ta, să fac asta, credință am în nevinovăția voastră!

Brâncoveanu, șezând, purtând încă pe cap, cuca găsi un răspuns diplomatic desigur trist oricât de împăciutor ar fi vrut să fie.

- Măcar bine că domnia nu i-a fost încredințată unui străin. E bine pentru țară.

Peste puțină vreme Brâncoveanu se înbolnăvi de un erizipel și asta îtârzie plecarea sa la Constantinopol. Drumul pe care obligatoriu trebuia să-l facă, și chiar pe pământul țării, până la Dunăre, a fost un calvar, Brâncoveanu Domnul, fiind dus cu lanțuri la picioare, îmbrăcat doar în cămaşă lungă, la fel ca toți membrii familiei sale. Însoțit de câțiva boieri până la graniță și de către Cantacuzino, își păstră demnitatea nebănuind că va deveni un martir.

Trei săptămâni a durat până ce au ajuns la Constantinopol, în închisoarea Edicule. Aici începu şirul dramelor îndurate de domnitor și copiii săi. Un capitol zbuciumat, tragic, de neiertat în istorie. Umilințele nu le-au putut şterge din calendar nici memoria paginilor de istorie și nici viețile celor 200 de urmași ai săi, cunoscuți până astăzi și care 1-au pomenit neînceta. 